Egyptian Journal of Rabbit Science, 27 (2): 245- 266(2017)

\title{
EFFECTS OF ROSEMARY AND MARJORAM SUPPLEMENTATION ON GROWTH PERFORMANCE, DIGESTIBILITY AND ECONOMIC EFFICIENCY OF GROWING RABBITS
}

\author{
E.O.A. Bakr; Lobna A.M.A. Badawi; M.A. Abdel Ghaffar and M.R.M. \\ Mousa \\ Department of Animal and Poultry Production, Faculty of Environmental \\ Agricultural Sciences, Arish University, Egypt.
}

This study was conducted to investigate the effects of dietary inclusion of different levels of Rosemary and Marjoram plants ongrowth performance and digestion coefficientsof New Zealand White (NZW) rabbits. Seventy two weaned rabbits were divided into six groups. The $1^{\text {st }}$ group was fed basal diet and served as control group, the $2^{\text {nd }}$ and $3^{\text {rd }}$ groups were fed the basal diet supplementedwithRosemary dry plant powder $(1.5 \%$ and $3.0 \%$, respectively), $4^{\text {th }}$ and $5^{\text {th }}$ groups were fed the basal diet supplemented with Marjoram dryplant powder (1.5\% and $3.0 \%$, respectively), the $6^{\text {th }}$ group was fed the basal diet supplemented with mixture of (1. 5\% Rosemary dry $+1.5 \%$ Marjoram dry). At the end of the experiment eighteen rabbit males were used in digestibility trail. Carcass traits and blood metabolites were determined by slaughtering 3 rabbits from each group at the end of the growth period.

The obtained results revealed that,final body weight and daily body weight gain were significantly $(P \leq 0.05)$ higher with $1.5 \%$ rosemary, $1.5 \%$ marjoram and their mixture compared to control and other treatment groups. Feed conversion significantly $(P \leq 0.05)$ improved in rabbits fed diet containing $1.5 \%$ marjoram compared with control group. Also, rabbits fed diet supplemented with $1.5 \%$ marjoramshowed the lowest $(P \leq 0.05)$ feed intake compared with control group and other treatments.

The digestibility of DM, OM, $C P$ and EE and NFE, significantly $(P \leq 0.05)$ improved with diet supplemented with $1.5 \%$ rosemary. The same trend was observed in TDN\%. However, The DCP \% in rabbits fed diet supplemented with $1.5 \%$ rosemary and $1.5 \%$ marjoram was significantly $(p \leq 0.05)$ higher than of those the other diets. Rabbits fed diet with $1.5 \%$ rosemary and 3\% marjoram significantly increased dressing percentage. 
Rabbit of the $3 \%$ rosemary group had higher $(P<0.05)$ blood globulin level. Serum glucose significantly increased in group fed mixture $(1.5 \%$ rosemary $+1.5 \%$ marjoram).Rabbit of the $3 \%$ marjoram group had higher $(P<0.05)$ blood cholesterol and total lipids. Rabbit of the $3 \%$ rosemary group had higher $(P<0.05)$ blood globulin and creatinine. Serum blood AST and ALT increased $(P \leq 0.05)$ in rabbits fed $3 \%$ rosemary. Feeding growing rabbits in control, 1.5 rosemary and $1.5 \%$ marjoram had a significant tendency $(P \leq 0.05)$ to increase serum hemoglobin and hematocrit . Rabbits fed diets without any medicinal additives had significant $(P \leq 0.05)$ red blood cells.

In conclusion, inclusion of $1.5 \%$ of rosemary (Rosmarinus officinalis) or marjoram (Origanum majorana) plants in NZW rabbit rations as a natural source of antioxidants improved live body weight, body weight gain, carcass traits, digestibility of nutrients and economic efficiency under north Sinai conditions without any adverse effects in on performance.

Keywords: Rosemary; Marjoram; growth performance; nutrient digestibility; carcass traits; blood parameters

There are a large number of feed additives available for inclusion in rabbit's diets to improve their performance (Ewuolaet al.,2011). However, the use of chemical products especially (hormones and antibiotics), may cause unfavorable side effects. Moreover, there is evidence indicating that these products are currently considered as risky pollutants for human and may threaten their health on the long-run (Omeret al., 2013).

Currently, there is an increasing interest in using herbs in animal nutrition, in order to replace the use of antibiotics and ionophore anticoccidials. Herbs, Medicinal and aromatic plants are preferable as feed additives and growth promoters causing safe improvements in growth traits, feed intake, feed conversion and nutrient digestibilityin rabbits, chicks, sheep, cows or buffaloes (Aboul-fotouh et al., 1999, EL-Ayek, 1999 and Allam et al., 2005), body weight gain, growth performance and mortality rate (Ibrahim, 2005 and Tipuet al., 2006), carcass traits (Evans and Pharm, 1975) and physical conditions of gut ecosystem (Guo, 2003).

Accordingly, the current study was carried out to evaluate the effects of Rosemary (Rosmarinus officinalis L.) and Marjoram (Origanum majorana L.) plantsalone or the mixture on growth performance, nutrient 
EFFECTS OFROSEMARY \& MARJORAM SUPPLEMENTATION ONRABBITS 247

digestibility, carcass characteristics, blood constituents and economical evaluation under the prevailed circumstances of North Sinai, Egypt.

\section{MATERIALS ANDMETHODS}

The present study was carried out at rabbit research farm of Animal and Poultry Production Department, Faculty of Environmental Agriculture Sciences, Arish University from March to May 2015. The geographical and climatic characteristics of this region (Long. , 33.75E and Lat. $31.27 \mathrm{~N}$ ) is semi- arid with an average annual rain fall of about $94 \mathrm{~mm}$ and average ambient temperature of about $20.47^{\circ} \mathrm{C}$.

Rosemary (Rosmarinus officinalis L.) and Marjoram (Origanum majorana L.) plants were collected from a private commercial farm located in North Sinai governorate. The plants were air-dried under shade until the moisture of collected plants roughly reached $10 \%$. The plants were finally milled, sieved ( $1 \mathrm{~mm}$ mesh) and stored in a well tight polyethylene bags at room temperature of $25^{\circ} \mathrm{C}$.

This study was carried out to study the effects of either dietary Rosemary or Marjoram on growth performance of growing rabbits. A total number of 72 ( 36 males and 36 females) weaned NZW rabbits with 5 weeks of age were weighed $(560 \pm 20.5 \mathrm{~g})$ and were randomly assigned to the six groups(12 each). Each group was distributed into 4 replicates ( 2 males and 2 females). The first group fed a basildiet without supplementation, second and third groups were fed the control diet supplemented withrosemary dry plant $(1.5 \%$ or $3.0 \%$, respectively), the fourth and fifth groups were fed the basal diet supplemented with marjoram dry plant $(1.5 \%$ or $3.0 \%$, respectively), while the sixth group was fed the basal diet supplemented with mixture of ( $1.5 \%$ rosemary dry plant $+1.5 \%$ marjoram dry plant $)$.

The rabbits were housed in galvanized cages commercial type measured $(40 \times 40 \times 25 \mathrm{~cm})$. The cages were provided with feeders and automatic nipple drinkers. Feed and water were available ad libitum during the experimental period ( 8 weeks. All rabbits were kept under the same managerial, hygienic and environmental conditions. Live body weight and feed consumption were weekly recorded. Body weight gain and feed conversion ratio were calculated.

Rabbits were feddiets to cover their requirementsaccording to NRC (1977). The formulation andcalculated analysis of the experimental diet were shown in Table 1. 
Table 1. Ingredients of experimental diet used in this study.

\begin{tabular}{lc}
\hline Ingredients, \% & Con. diet \\
\hline Yellow corn & 14 \\
Barley grain & 10 \\
Wheat bran & 27 \\
Soybean meal 44\% & 12 \\
Alfalfa hay & 31.5 \\
Molasses & 3 \\
Dicalcium P. & 1.2 \\
Calcium carbonate (lime stone) & 0.6 \\
Sodium chloride (salt) & 0.3 \\
Premix & 0.3 \\
Methionine & 0.1 \\
\hline Total & $\mathbf{1 0 0}$ \\
\hline Calculated chemical composition & \\
Crude protein (CP) & 17.38 \\
Crude fiber (CF) & 12.27 \\
Ether extract (EE) & 2.93 \\
Digestible energy (Kcal/Kg) & 2769.70 \\
\hline Ong & klogra, Vit.
\end{tabular}

One kilogram of premix contain: Vit. A $12000000 \mathrm{IU}, \mathrm{Vit}_{2} \mathrm{D}_{3} 220000 \mathrm{IU}$, Vit. E $1000 \mathrm{mg}$, Vit.K $2000 \mathrm{mg}$, Vit.B $1000 \mathrm{mg}$, Vit.B $4000 \mathrm{mg}$, Vit.B $100 \mathrm{mg}$, Vit. $\mathrm{B}_{12} 10$ $\mathrm{mg}$, Pantothenic acid $3.33 \mathrm{~g}$, Biotin $33 \mathrm{mg}$, Folic acid $0.83 \mathrm{~g}$, Choline chloride $200 \mathrm{~g}$, Zn 11.79 g, Mn 5 g, Fe 12.5 g, Cu 0.5 g, I 33.3 mg, Se $16.6 \mathrm{mg}$ and $\mathrm{Mg} 66.7 \mathrm{~g}$.

At the termination of growth period, eighteen rabbits were used for digestibility trial whichconsisted of 7 days as a preliminary period followed by 5 days collection period. During the collection period, daily faces of each animal were taken, cleaned from hair and dried at $70^{\circ} \mathrm{C}$ for 48 hour and stored in polyethylene bags until chemical analysis. Samples of feed and feces were chemically analyzed according to A.O.A.C. (2010).

Digestible energy (DE) of one kilogram of each experimental diet was calculated according to the equation described by Schiemann et al., (1972), cited by El-Kerdawy et al., (1998) as follows:

$\mathrm{DE} \quad(\mathrm{kcal} / \mathrm{kg})=5.29 \quad(\mathrm{DCP}, \quad \mathrm{g} / \mathrm{kg}) \quad+9.51 \quad(\mathrm{DEE}, \mathrm{g} / \mathrm{kg})+4.2$ $(\mathrm{DCF}+\mathrm{DNFE}, \mathrm{g} / \mathrm{kg}) \pm 0.30$. Where DCP, DEE, DCF and DCNFE= digestible $\mathrm{CP}, \mathrm{EE}, \mathrm{CF}$ and NFE, respectively

At the end of the growthtrail, three representative rabbits from each treatment were randomly chosen and fasted for 16 hours before slaughtering according to Steven et al., (1981) to determine the carcass traits.

At slaughter time blood samples were collected. Half of eachsamplewasexpelled gradually into graduated tubes containing heparin; then, tubes were immediately capped and mixed gently by repeated 
inversion. The rest of the samples were collected in sterile tubes without anticoagulant. All blood samples were transported to the laboratory at $+4^{\circ} \mathrm{C}$ within 3 hours. Serum was centrifuged at 3,000 rpm for $20 \mathrm{~min}$ and frozen at $-20^{\circ} \mathrm{C}$ for biochemical analyses. Hematological analyses on heparin samples were completed on the day of collection.

The serum total protein was determined by the Biuret method (Reinhold, 1953) using a commercial kit (Randox Laboratories Ltd, U.K.), while the albumin value was obtained by bromocresol green method (Henry and Cannon, 1974). The globulin and albumin-globulin ratio were determined according to the method of Coles (1986). The serum urea nitrogen and creatinine were determined according to the methods described by Patton and Crouch, (1977) and Husdan and Rapoport (1968) respectively. Also the free cholesterol and glucose were determined as described by (Deutsche Veterinaer Medizinische Gesellschaft, 1976), Total lipids were determined by the colorimetric determination according to (Schmit, 1964) using sulfophospho vanillic mixture. While the serum enzymes Alanine aminotransferase (ALT) and Aspartate aminotransferase (AST) were assayed by the methodof Reitman and Frankel (1957).

Blood haemoglobin ( $\mathrm{Hb}$ ) and platelets (PLT) were determined colorimetrically using readymade kits provided by Randox, United Kingdom, using cyanomethaemoglobin method according to Schalm (1979). Red blood cell (RBCs) counts and total white blood cell (WBCs) counts concentration parameters were determined following standard procedures described by Bauer (1970). Packed cell volume (PCV \%) was determined according to Wintrobe (1967).

Mean Corpuscular Hemoglobin $(\mathrm{MCH})(\mathrm{Pg})=\mathrm{HbX10} /$ Red blood cell.

Mean Corpuscular Hemoglobin Concentration $(\mathrm{MCHC})(\mathrm{g} / \mathrm{dl})=$ $\mathrm{HbX100/Packed} \mathrm{cell} \mathrm{volume.} \mathrm{MCV}=(\mathrm{PCV} \% \times 10) / \mathrm{RBC}$

The prevailing market prices of ingredients and medicinal plants used during the period of the study were used for the economic evaluation of the feeds.

Economic efficiency is defined as the net revenue per unit feed cost calculated from input output analysis as described by Asar et al., (2010).

The economic efficiency was calculated by the following:

Feed cost $=$ number of $\mathrm{kg}$ feed per rabbit $\mathrm{x}$ price of $\mathrm{kg}$ feed.

Selling revenue $=$ Body weight gain per rabbit $\mathrm{x}$ Price of $\mathrm{kg}$ for live body weight.

Net revenue $=$ Difference between selling revenue and feed cost.

E.FE $($ Economic feed efficiency $)=($ net revenue/feed cost $) \times 100$.

R.E.E (Relative economic efficiency), assuming control treatment $=100 \%$. 
Data were analyzed using general linear model procedure of SAS software (SAS Institute, 2004). Difference among treatment means were tested for significance using Duncan's Multiple Range Test (Duncan, 1955).

\section{RESULTS AND DISCUSSION}

\section{Feeding values of medicinal plants:}

Data presented in Table (2) showed the chemical composition of Rosemary (Rosmarinus officinalis L.) and Marjoram (Origanum majorana L.) and tested diets. The highest value of crude protein and ash were observed of Marjoram (13.22 and8.62\%), while the lowest (5.02and 5.23\%) were recorded with Rosemary. However, the highest value of ether extract, crude fiber and nitrogen free extract were recorded withRosemary (9.23, 21.71 and $58.81 \%$, respectively), while the lowest value (3.21, 19.07 and $55.88 \%$, respectively) were recorded with Marjoram. The obtained results are in agreement with (Ghazalah and Ali ,2008, Osman et al. 2010 and Ali, 2014).

Table 2. Chemical analysis (\%) of medicinal plants and the experimental diets.

\begin{tabular}{lcccccccc}
\hline Items & \multirow{7}{*}{ DM } & \multicolumn{7}{c}{ \% On DM basis } \\
\cline { 3 - 8 } & & OM & CP & EE & CF & NFE & ASH \\
\hline Rosemary & 89.96 & 94.77 & 5.02 & 9.23 & 21.71 & 58.81 & 5.23 \\
Marjoram & 89.82 & 91.38 & 13.22 & 3.21 & 19.07 & 55.88 & 8.62 \\
\hline Chemical composition of experimental diets & given to & NZW rabbits \\
Control & 90.53 & 91.40 & 17.38 & 2.93 & 12.26 & 58.83 & 8.60 \\
Rosemary 1.5\% & 90.20 & 91.45 & 17.19 & 3.02 & 12.40 & 58.84 & 8.55 \\
Rosemary 3\% & 89.58 & 91.50 & 17.01 & 3.20 & 12.54 & 58.75 & 8.50 \\
Marjoram 1.5\% & 90.20 & 91.40 & 17.32 & 2.93 & 12.36 & 58.79 & 8.60 \\
Marjoram 3\% & 90.50 & 91.40 & 17.26 & 2.94 & 12.46 & 58.74 & 8.60 \\
Mixture & 90.40 & 91.45 & 17.13 & 3.03 & 12.50 & 58.79 & 8.55 \\
\hline
\end{tabular}

\section{Live body weight and body weight gain:}

Results of live body weight and body weight gain are shown in Table 3. Feeding rabbits diets supplemented with the $1.5 \%$ rosemary, $1.5 \%$ marjoram and their mixture $(1.5 \%$ rosemary $+1.5 \%$ marjoram $)$ significantly $(\mathrm{P} \leq 0.05)$ increased final live body weight $(2117.67,2139.67$ and $2129.25 \mathrm{~g}$, respectively) and daily body weight gain $(25.65,25.95$ and $25.83 \mathrm{~g} / \mathrm{d}$, respectively ) compared with the control group and the other treatments. 
EFFECTS OF ROSEMARY \& MARJORAM SUPPLEMENTATION ONRABBITS 251 
In this respect, .Osman et al. (2010) and Ali (2014) with broiler and Seleemet al. (2007) with growing New Zealand rabbits indicated that body weight and gain in weight were significantly improved by feeding various levels of Origanum majorana.. In addition, Ahmed and Abdel-Ghany (2015) observed that diet containing 0.8\% Origanummajorana significantly improved body weight and weight gain in turkey. In contrary, Taha et al., (2011) found no significant effect on body weight and weight gain of broiler fed diet containing $0,2.5,5.0$ or $7.5 \mathrm{~g} / \mathrm{kg}$ of Oregano.

For rosemary, ELnaggar et al., (2016). observed that broilers chicks fed 0.25 and $0.5 \%$ rosemary leaves meal had significantly $(\mathrm{P}<0.05)$ increased in live body weight and body weight gain than those fed diet with, 0.75 and $1.0 \%$ of rosemary leaves and control group.On the other hand, El-Wardany et al. (2015) found that no significant effects in growing rabbits fed diets supplemented with 0.5 or $1 \%$ rosemary dry leaves on growth performance.

These progressive positive effects of marjoram and rosemary on live body weight and body weight gain may be due to the ability of these plants to increase the efficiency of digestion by increasing digestive enzymes and saliva, calming the stomach and digestive system, improving appetite, curing or preventing basic intestinal infections and relieving diarrhea and constipation (Hallnet, 2014). Also, Ezz El-Arab, (2008) mentioned that, ability of natural feed additives to enhance animal appetite, is due to the fact that it is rich in a wide variety of secondary metabolites, such as, trepenoids, which have been found to have antimicrobial properties (Cowan, 1999), and antioxidant activity (Triantaphyllou et al., 2001), which in turn improves the lower gut health, bacterial population, improves nutrients absorption, utilization and eventually improves bird's health and increases body weight and weight gain.

\section{Feed Intake and conversion}

Feed intake and conversion data of rabbits fed diets supplemented with natural feed additives (rosemary and marjoram) are presented in Table (3). Generally, it is clear that growing rabbits fed diets supplemented with $1.5 \%$ rosemary consumed significantly more feed $(\mathrm{P} \leq 0.05)$ of $116.81 \mathrm{~g}$ compared with control group and other treatments. While, rabbits fed diets with marjoram at $1.5 \%$ consumed the lowest amounts (106.69 g) as compared with that of the other dietary treatments, and the control group.

These results are in agreement with Ghazalah and Ali (2008) who found that $0.5 \%$ rosemary herb supplementation in the diet gave better feed intake than the control treatment at 49 days of age. On the other hand, in 


\section{EFFECTS OFROSEMARY \& MARJORAM SUPPLEMENTATION ONRABBITS 253}

growing rabbits, El-Wardany et al. (2015) found that no significant effects on feed intake when using diets supplemented with rosemary leaves.

The marjoram results are in agreement with those obtained by Ali (2014) and Ahmed and Abdel-Ghany (2015) reported significant decrease of feed intake with addition of marjoram to broiler diet during most the age periods.

Feeding growing NZW rabbits on diets supplemented with of marjoram at the lower level $(1.5 \%)$ significantly $(\mathrm{P}<0.05)$ improved feed conversion ratio (4.11g feed/g gain) followed by rabbits fed diet supplemented with mixed (4.26 g feed/g gain)) compared with the other dietary treatments, and the control group, which had the highest feed conversion value of $4.80 \mathrm{~g}$ feed/g gain. This results agreement with, (Seleemet al. 2007, Osman et al.2010 and Ali 2014)they found improvement in New Zealand White and broiler forfeed conversion when feeding diets containing marjoram versus control. In contrast, Ahmed and Abdel-Ghany (2015) reported that feeding diets containing 0.4 or $0.8 \%$ marjoram to turkey diets insignificantly improved effect in daily feed intake and feed conversion ratio.

The previous results may be due to the ability of this plants to increase the efficiency of digestion by increasing digestive enzymes, curing or preventing basic intestinal infections and relieving diarrhea which resulting in maximizes the benefit of feed without increase in feed intake (Hallent, 2014).

\section{Economic efficiency:}

The economic efficiency of dietary treatments is presented in Table 3. Costing of one $\mathrm{kg}$ feed, (LE) was increased byinclusion medicinal plants in the diets compared to control diet. It is obvious that feeding dietary supplemented treatments increased the feed cost (LE/60) as compared to that of the control. It is worthy to note that supplementing low level $(1.5 \%)$ of marjoram to the basal diet resulted in decreasing in feed cost $(17.15$ L.E) followed with the control group (17.42 L.E) compared with other dietary treatments. Rabbits received $1.5 \%$ rosemary, marjoram and their mixture recorded the best totalrevenue, net revenue, economical efficiency and relativeeconomic efficiency compared with control and other treatments. These results agree with the findings of (Abdel El-Latif et al., 2004 and Osman et al., 2010).

\section{Digestibility coefficients and nutritive values:}

Results given in Table (4) showed that the digestion coefficients of nutrients as affected by the different supplementation with Rosemary and 
Table 4. Digestibility and nutritive value of growing rabbits fed basal diet supplemented with levels of Rosemary and Marjoram.

\begin{tabular}{|c|c|c|c|c|c|c|}
\hline \multirow[b]{2}{*}{ Items } & \multicolumn{6}{|c|}{ Experimental diets (\%) } \\
\hline & Control & $\begin{array}{c}\text { Rosemary } \\
1.5 \\
\end{array}$ & $\begin{array}{c}\text { Rosemary } \\
\mathbf{3 . 0} \\
\end{array}$ & $\begin{array}{c}\text { Marjoram } \\
1.5 \\
\end{array}$ & $\begin{array}{c}\text { Marjoram } \\
\mathbf{3 . 0} \\
\end{array}$ & $\begin{array}{c}\text { Mixture } \\
(1.5+1.5 \%)\end{array}$ \\
\hline \multicolumn{7}{|c|}{ n coefficients \% } \\
\hline \multirow[t]{2}{*}{ DM } & $63.22^{\mathrm{b}}$ & $65.80^{\mathrm{a}}$ & $62.90^{\mathrm{b}}$ & $64.88^{\mathrm{ab}}$ & $62.58^{\mathrm{b}}$ & $63.62^{\mathrm{ab}}$ \\
\hline & \pm 1.13 & \pm 0.28 & \pm 0.95 & \pm 0.78 & \pm( & 36 \\
\hline \multirow[t]{2}{*}{$\mathbf{O M}$} & $67.45^{\mathrm{b}}$ & $70.37^{\mathrm{a}}$ & $67.10^{\mathrm{b}}$ & $68.82^{\mathrm{ab}}$ & $67.14^{\mathrm{b}}$ & $68.13^{\mathrm{ab}}$ \\
\hline & \pm 1.13 & \pm 0.2 & \pm 0.87 & \pm & \pm 0.32 & \pm 0.53 \\
\hline \multirow[t]{2}{*}{$\mathbf{C P}$} & $72.12^{\mathrm{bc}}$ & $76.10^{\mathrm{a}}$ & $72.80^{\mathrm{abc}}$ & $75.37^{\mathrm{ab}}$ & $74.36^{\mathrm{abc}}$ & $71.63^{\mathrm{c}}$ \\
\hline & \pm 1.9 & \pm 0 & \pm 0.86 & & \pm & \pm 0.62 \\
\hline \multirow[t]{2}{*}{ EE } & $72.00^{\mathrm{b}}$ & $77.74^{\mathrm{a}}$ & $73.77^{\mathrm{ab}}$ & $73.03^{\mathrm{b}}$ & $73.51^{\mathrm{ab}}$ & $72.80^{\mathrm{b}}$ \\
\hline & \pm 1 & \pm 1 & \pm 0.58 & \pm 1 & \pm 1.12 & \pm 1.06 \\
\hline \multirow[t]{2}{*}{$\mathbf{C F}$} & 34.69 & 36.13 & 34.60 & 36.82 & 32.30 & 34.69 \\
\hline & \pm 1.75 & \pm 3.77 & \pm 2.99 & \pm 1.77 & \pm 0.51 & \pm 2.69 \\
\hline \multirow[t]{2}{*}{ NFE } & $72.89^{\mathrm{b}}$ & $75.61^{\mathrm{a}}$ & $72.85^{\mathrm{b}}$ & $73.27^{\mathrm{ab}}$ & $72.82^{\mathrm{b}}$ & $73.25^{\mathrm{ab}}$ \\
\hline & \pm 0.84 & & & & & \\
\hline \multicolumn{7}{|c|}{ Nutritive value (\%) } \\
\hline \multirow[t]{2}{*}{ TDN } & $64.41^{\mathrm{b}}$ & $67.33^{\mathrm{a}}$ & $64.79^{\mathrm{b}}$ & $65.52^{\mathrm{b}}$ & $64.41^{\mathrm{b}}$ & $63.98^{\mathrm{b}}$ \\
\hline & \pm 1.00 & \pm 0.22 & \pm 0.41 & \pm 0.52 & \pm 0.08 & \pm 0 \\
\hline \multirow[t]{2}{*}{ DCP } & $12.87^{\mathrm{ab}}$ & $13.07^{\mathrm{a}}$ & $12.65^{\mathrm{ab}}$ & $13.05^{\mathrm{a}}$ & $12.83^{\mathrm{ab}}$ & $12.27^{\mathrm{b}}$ \\
\hline & \pm 0.41 & \pm 0.12 & \pm 0.13 & \pm 0.09 & \pm 0.14 & \pm 0.11 \\
\hline DE & $2841.90^{\mathrm{b}}$ & $2971.12^{\mathrm{a}}$ & $2872.24^{\mathrm{b}}$ & $2893.01^{\mathrm{ab}}$ & $2849.76^{\mathrm{b}}$ & $2849.03^{b}$ \\
\hline (kcal/kg) & \pm 45.96 & \pm 10.08 & \pm 31.42 & \pm 22.07 & \pm 5.47 & \pm 15.28 \\
\hline
\end{tabular}

different $(\mathrm{P}<0.05)$.

Marjoram. It could be observed that digestibility coefficients of DM, OM, $\mathrm{CP}$, EE and NFE increased significantly $(\mathrm{P} \leq 0.05)$ by feeding NZW growing rabbit on diets supplemented with $1.5 \%$ rosemary compared with the other treatments. On the other hand, digestion coefficients of CF showed no significant differences among treatments. The present results are in agreement with those obtained by Abd El-Galil (2007) who found that feeding Japanese quail on $0.5,1.0$ and $1.5 \mathrm{gm}$. marjoram leaves $/ \mathrm{kg}$ diet improved $(\mathrm{P} \leq 0.05)$ digestibility coefficients of OM; CP; CF; EE and NFE when compared with control group. Medicinal plants could have stimulated the appetite of rabbits, enhanced the process of digestion and absorption of food and encouraged secretion of different digestive enzymes of the stomach (Tipu et al., 2006).

The present results showed that the total digestible nutrients (TDN) and digestible energy (DE) values were increased $(\mathrm{P} \leq 0.05)$ for diet 


\section{EFFECTS OFROSEMARY \& MARJORAM SUPPLEMENTATION ONRABBITS 255}

supplemented with $1.5 \%$ rosemary compared with control group and other treatments (Table, 4). The nutritive values as digestible crude protein (DCP) significantly increased $(\mathrm{P} \leq 0.05)$ when rabbits were fed diets supplemented with $1.5 \%$ rosemary and $1.5 \%$ marjoram compared with the other treatments (Table, 4). These results are in agreement with, Abousekkenet al., (2007) found that growing rabbit group fed $36 \%$ mixture of fennel and Marjoram significantly had the best TDN compared with control group. On the other hand, Aboelazab (2015)observed no significant effect on digestibility of DM, NDF, ADF and $\mathrm{CP}$ when growing rabbits fed diets containing $0.5 \%$ and $1.0 \%$ rosemary leaves.

\section{Carcass traits}

Data of carcass traits of the growing rabbits at 90 days fed diets supplemented with natural feed additives (rosemary and marjoram and their mixture) are summarized in Table 5.

Dietary treatment had no significantly affect $(\mathrm{P}>0.05)$ onpre slaughter, carcass weight, head, kidney, and heart weights compared to the control group.Rabbits fed diet supplemented with $1.5 \%$ marjoram had highest values for fur and lung weights (333.00 and $12.71 \mathrm{~g}$, respectively) compared with control group and other treatments. However, rabbits fed high marjoram level (3\%) were the best liver and spleenweight (58.12 and $1.32 \mathrm{~g}$, respectively) compared with control group and other treatments. Supplemented growing rabbit diet with $1.5 \%$ rosemary significantly $(\mathrm{P} \leq 0.05)$ increased tests weight $(8.64 \mathrm{~g})$ compared with control group and other treatments.Feeding growing rabbits diets supplemented with $1.5 \%$ and $3 \%$ of marjoram increased dressing percentage (66.86 and 66.45, respectively) compared with the other treatments. These results may be attributed to growth promoting effects of medicinal plants and to enhancement of metabolism of essential and volatile oils included in medicinal plants (Evans and Pharm, 1975).

These results agreement withSeleemet al. (2007) who reported that supplementing Origanummajorana to growing diets of New Zealand White rabbits significantly increased dressing percentage by 6.1\%.Also,Omer et al. (2013) indicated that relative to the slaughter weight, hot carcass, giblets, and total edible parts percentage, were not significantly affected by supplement of $1 \%$ oregano. Same trend was observed by, bits.

For rosemary, ELnaggar et al., (2016). showed that broilers chicks fed $0.25 \%$ rosemary leaves meal had significantly $(\mathrm{P}<0.05)$ higher dressing percentage and edible parts than that in control and 0.50 and those having 
Table 5. Effect of dietary levels of natural feed additives on carcass traits and dressing percentage of growing NZW rabbits.

\begin{tabular}{|c|c|c|c|c|c|c|}
\hline \multirow{3}{*}{ Items } & \multicolumn{6}{|c|}{ Treatments } \\
\hline & \multirow[t]{2}{*}{ Control } & \multicolumn{2}{|c|}{$\begin{array}{c}\text { Rosemary } \\
(\%)\end{array}$} & \multicolumn{2}{|c|}{$\begin{array}{c}\text { Marjoram } \\
(\%)\end{array}$} & \multirow[t]{2}{*}{ Mixture } \\
\hline & & 1.5 & 3.0 & 1.5 & 3.0 & \\
\hline \multicolumn{7}{|l|}{ Traits weight (gm.): } \\
\hline Pre-slaughter wt. & $\begin{array}{c}2083 \\
\pm 76.00\end{array}$ & $\begin{array}{c}2102.67 \\
\pm 19.52\end{array}$ & $\begin{array}{l}2033.33 \\
\pm 88.19\end{array}$ & $\begin{array}{c}2020.33 \\
\pm 10.33\end{array}$ & $\begin{array}{l}2097.67 \\
\pm 134.04\end{array}$ & $\begin{array}{c}2213.33 \\
\pm 20.48\end{array}$ \\
\hline Carcass wt. & $\begin{array}{l}1327.33 \\
\pm 59.74\end{array}$ & $\begin{array}{l}1383.33 \\
\pm 60.11\end{array}$ & $\begin{array}{l}1334.67 \\
\pm 35.05\end{array}$ & $\begin{array}{l}1412.00 \\
\pm 18.58\end{array}$ & $\begin{array}{l}1396.33 \\
\pm 109.88\end{array}$ & $\begin{array}{l}1370.33 \\
\pm 24.03\end{array}$ \\
\hline Head wt. & $\begin{array}{l}122.33 \\
\pm 5.93\end{array}$ & $\begin{array}{l}117.00 \\
\pm 5.57\end{array}$ & $\begin{array}{l}118.67 \\
\pm 4.58\end{array}$ & $\begin{array}{l}120.00 \\
\pm 2.89\end{array}$ & $\begin{array}{l}118.67 \\
\pm 6.94\end{array}$ & $\begin{array}{l}121.33 \\
\pm 0.882\end{array}$ \\
\hline Fur wt. & $\begin{array}{l}305.33^{\mathrm{a}} \\
\pm 10.33\end{array}$ & $\begin{array}{c}311.00^{\mathrm{a}} \\
\pm 6.43\end{array}$ & $\begin{array}{l}296.00^{b} \\
\pm 11.53\end{array}$ & $\begin{array}{l}333.00^{\mathrm{a}} \\
\pm 17.04\end{array}$ & $\begin{array}{l}284.67^{b} \\
\pm 29.06\end{array}$ & $\begin{array}{c}321.00^{\mathrm{a}} \\
\pm 8.33\end{array}$ \\
\hline Liver wt. & $\begin{array}{c}50.81^{\mathrm{ab}} \\
\pm 1.67\end{array}$ & $\begin{array}{c}54.85^{\mathrm{ab}} \\
\pm 2.38\end{array}$ & $\begin{array}{l}45.97^{b} \\
\pm 6.37\end{array}$ & $\begin{array}{c}48.44^{\mathrm{ab}} \\
\pm 3.74\end{array}$ & $\begin{array}{l}58.12^{\mathrm{a}} \\
\pm 5.08\end{array}$ & $\begin{array}{c}47.29^{\mathrm{ab}} \\
\pm 5.29\end{array}$ \\
\hline Kidneys wt. & $\begin{array}{l}12.72 \\
\pm 0.68\end{array}$ & $\begin{array}{l}12.41 \\
\pm 1.24\end{array}$ & $\begin{array}{c}13.62 \\
\pm 1.110\end{array}$ & $\begin{array}{l}12.87 \\
\pm 0.29\end{array}$ & $\begin{array}{l}14.11 \\
\pm 1.01\end{array}$ & $\begin{array}{l}12.71 \\
\pm 1.01\end{array}$ \\
\hline Heart wt. & $\begin{array}{c}5.63 \\
\pm 0.41\end{array}$ & $\begin{array}{c}6.29 \\
\pm 0.27\end{array}$ & $\begin{array}{c}6.08 \\
\pm 0.84\end{array}$ & $\begin{array}{c}5.56 \\
\pm 0.32\end{array}$ & $\begin{array}{c}5.37 \\
\pm 0.49\end{array}$ & $\begin{array}{c}6.71 \\
\pm 0.19\end{array}$ \\
\hline Lungs wt. & $\begin{array}{l}10.11^{\mathrm{ab}} \\
\pm 1.93\end{array}$ & $\begin{array}{l}10.49^{\mathrm{ab}} \\
\pm 1.68\end{array}$ & $\begin{array}{l}9.37^{b} \\
\pm 1.37\end{array}$ & $\begin{array}{l}12.71^{\mathrm{a}} \\
\pm 1.11\end{array}$ & $\begin{array}{l}12.04^{\mathrm{a}} \\
\pm 0.77\end{array}$ & $\begin{array}{c}10.19^{\mathrm{ab}} \\
\pm 0.32\end{array}$ \\
\hline Spleen wt. & $\begin{array}{c}0.52^{\mathrm{b}} \\
\pm 0.044\end{array}$ & $\begin{array}{c}0.53^{\mathrm{b}} \\
\pm 0.046\end{array}$ & $\begin{array}{l}1.08^{\mathrm{a}} \\
\pm 0.17\end{array}$ & $\begin{array}{l}0.91^{\mathrm{ab}} \\
\pm 0.13\end{array}$ & $\begin{array}{r}1.32^{\mathrm{a}} \\
\pm 0.44\end{array}$ & $\begin{array}{l}0.71^{\text {ab }} \\
\pm 0.03\end{array}$ \\
\hline Tests wt. & $\begin{array}{l}6.64^{\text {ab }} \\
\pm 1.75\end{array}$ & $\begin{array}{l}8.64^{\mathrm{a}} \\
\pm 0.66\end{array}$ & $\begin{array}{l}7.11^{\text {ab }} \\
\pm 0.26\end{array}$ & $\begin{array}{l}6.64^{\mathrm{ab}} \\
\pm 1.26\end{array}$ & $\begin{array}{l}7.19^{\text {ab }} \\
\pm 0.43\end{array}$ & $\begin{array}{c}5.09^{\mathrm{b}} \\
\pm 0.035\end{array}$ \\
\hline Abdominal fat wt. & $\begin{array}{l}19.83^{\mathrm{c}} \\
\pm 3.91\end{array}$ & $\begin{array}{l}46.18^{\mathrm{a}} \\
\pm 7.00\end{array}$ & $\begin{array}{c}33.56^{\mathrm{b}} \pm 5 . \\
11\end{array}$ & $\begin{array}{l}30.07^{b} \\
\pm 6.32\end{array}$ & $\begin{array}{r}42.52^{\mathrm{a}} \\
\pm 18.74\end{array}$ & $\begin{array}{l}22.57^{\mathrm{c}} \\
\pm 4.87\end{array}$ \\
\hline Dressing, \% & $\begin{array}{l}63.01^{\mathrm{ab}} \\
\pm 0.410\end{array}$ & $\begin{array}{c}64.63^{\mathrm{ab}} \\
\pm 2.28\end{array}$ & $\begin{array}{l}60.85^{b} \\
\pm 0.15\end{array}$ & $\begin{array}{l}66.81^{\mathrm{a}} \\
\pm 0.61\end{array}$ & $\begin{array}{l}66.45^{\mathrm{a}} \\
\pm 1.19\end{array}$ & $\begin{array}{c}64.61^{\mathrm{ab}} \\
\pm 0.87\end{array}$ \\
\hline
\end{tabular}

$\mathrm{a}, \mathrm{b}$, and $\mathrm{c}$ : means within the same row with different superscripts are significantly different $(\mathrm{P}<0.05)$.

$0.75 \%$ of rosemary leaves. On the other hand, Aboelazab (2015) showed that carcass characteristic traits were not affected in treated rabbits when growing rabbits fed diets containing $0.5 \%$ and $1.0 \%$ rosemary leaves.

\section{Blood parameters}

\section{Biochemical parameters}

Serum biochemical parameters could be used as indicators of the nutritional and physiological status of experimental growing rabbits; data are presented in Table 6. It is obvious that dietary rosemary, marjoram or their mixture did not significantly affect total protein, albumin and $\mathrm{A} / \mathrm{G}$ ratio. 
EFFECTS OFROSEMARY \& MARJORAM SUPPLEMENTATION ONRABBITS 257

Table 6. Effect of dietary levels of natural feed additives on blood biochemical parameters of growing New Zealand White rabbits.

\begin{tabular}{|c|c|c|c|c|c|c|}
\hline \multirow[t]{3}{*}{ Items } & \multicolumn{6}{|c|}{ Treatments } \\
\hline & \multirow[t]{2}{*}{ Control } & \multicolumn{2}{|c|}{ Rosemary(\%) } & \multicolumn{2}{|c|}{ Marjoram(\%) } & \multirow[t]{2}{*}{ Mixture } \\
\hline & & 1.5 & 3.0 & 1.5 & 3.0 & \\
\hline $\begin{array}{l}\text { Blood metabolite } \\
\text { Total protein, } \\
(\mathrm{g} / \mathrm{dl})\end{array}$ & $\begin{array}{r}6.29 \\
\pm 0.12 \\
\end{array}$ & $\begin{array}{r}6.33 \\
\pm 0.15 \\
\end{array}$ & $\begin{array}{r}6.22 \\
\pm 0.07 \\
\end{array}$ & $\begin{array}{r}6.36 \\
\pm 0.16 \\
\end{array}$ & $\begin{array}{r}6.26 \\
\pm 0.110 \\
\end{array}$ & $\begin{array}{r}5.94 \\
\pm 0.18 \\
\end{array}$ \\
\hline Albumin, (g/dl) & $\begin{array}{c}4.80 \\
\pm 0.09 \\
\end{array}$ & $\begin{array}{r}4.56 \\
\pm 0.26 \\
\end{array}$ & $\begin{array}{c}4.43 \\
\pm 0.08 \\
\end{array}$ & $\begin{array}{c}4.70 \\
\pm 0.26 \\
\end{array}$ & $\begin{array}{c}4.84 \\
\pm 0.30 \\
\end{array}$ & $\begin{array}{r}4.42 \\
\pm 0.24 \\
\end{array}$ \\
\hline Globulin, (g/dl) & $\begin{array}{c}1.49^{\mathrm{ab}} \\
\pm 0.087 \\
\end{array}$ & $\begin{array}{l}1.76^{\mathrm{ab}} \\
\pm 0.11 \\
\end{array}$ & $\begin{array}{l}1.78^{\mathrm{a}} \\
\pm 0.13 \\
\end{array}$ & $\begin{array}{l}1.66^{\mathrm{ab}} \\
\pm 0.13\end{array}$ & $\begin{array}{l}1.42^{\mathrm{b}} \\
\pm 0.11 \\
\end{array}$ & $\begin{array}{l}1.52^{\mathrm{ab}} \\
\pm 0.06 \\
\end{array}$ \\
\hline A/ G ratio & $\begin{array}{c}3.25 \\
\pm 0.21\end{array}$ & $\begin{array}{c}3.41 \\
\pm 0.61\end{array}$ & $\begin{array}{c}2.52 \\
\pm 0.23\end{array}$ & $\begin{array}{c}2.92 \\
\pm 0.31\end{array}$ & $\begin{array}{c}3.48 \\
\pm 0.51\end{array}$ & $\begin{array}{c}2.92 \\
\pm 0.26\end{array}$ \\
\hline Glucose, (mg/dl) & $\begin{array}{c}109.87^{\mathrm{ab}} \\
\pm 5.54 \\
\end{array}$ & $\begin{array}{l}89.17^{\mathrm{c}} \\
\pm 1.12 \\
\end{array}$ & $\begin{array}{c}100.87^{\mathrm{bc}} \\
\pm 1.22\end{array}$ & $\begin{array}{l}93.97^{\mathrm{c}} \\
\pm 3.37 \\
\end{array}$ & $\begin{array}{l}113.87^{\mathrm{a}} \\
\mathrm{b} \pm 5.64\end{array}$ & $\begin{array}{c}118.20^{\mathrm{a}} \\
\pm 6.03\end{array}$ \\
\hline $\begin{array}{l}\text { Cholesterol, } \\
(\mathrm{mg} / \mathrm{dl})\end{array}$ & $\begin{array}{l}76.43^{\mathrm{c}} \\
\pm 1.13 \\
\end{array}$ & $\begin{array}{l}74.22^{\mathrm{c}} \\
\pm 1.74\end{array}$ & $\begin{array}{l}73.37^{\mathrm{c}} \\
\pm 0.94 \\
\end{array}$ & $\begin{array}{l}93.80^{\mathrm{b}} \\
\pm 0.70\end{array}$ & $\begin{array}{c}100.87^{\mathrm{a}} \\
\pm 2.23\end{array}$ & $\begin{array}{l}74.67^{\mathrm{c}} \\
\pm 0.96 \\
\end{array}$ \\
\hline $\begin{array}{l}\text { Total lipids, } \\
(\mathrm{mg} / \mathrm{dl})\end{array}$ & $\begin{array}{c}221.67^{\mathrm{c}} \\
\pm 1.20 \\
\end{array}$ & $\begin{array}{c}235.33^{\mathrm{abc}} \\
\pm 7.36 \\
\end{array}$ & $\begin{array}{c}227.67^{\mathrm{bc}} \\
\pm 1.21 \\
\end{array}$ & $\begin{array}{c}238.33^{\mathrm{ab}} \\
\pm 3.84 \\
\end{array}$ & $\begin{array}{c}249.00^{\mathrm{a}} \\
\pm 7.00 \\
\end{array}$ & $\begin{array}{r}225.00^{b} \\
c \quad \pm 3.46 \\
\end{array}$ \\
\hline $\begin{array}{l}\text { Kidney function } \\
\text { Urea-N, (mg/dl) }\end{array}$ & $\begin{array}{r}35.40 \\
\pm 1.91 \\
\end{array}$ & $\begin{array}{l}42.70 \\
\pm 3.34 \\
\end{array}$ & $\begin{array}{c}39.87 \\
\pm 0.755 \\
\end{array}$ & $\begin{array}{l}38.70 \\
\pm 1.37 \\
\end{array}$ & $\begin{array}{l}41.80 \\
\pm 3.45 \\
\end{array}$ & $\begin{array}{r}42.37 \\
\pm 1.410 \\
\end{array}$ \\
\hline $\begin{array}{l}\text { Creatinine, } \\
(\mathrm{mg} / \mathrm{dl})\end{array}$ & $\begin{array}{l}1.46^{\mathrm{ab}} \\
\pm 0.17\end{array}$ & $\begin{array}{r}1.83^{\mathrm{a}} \\
\pm 0.08\end{array}$ & $\begin{array}{c}1.55^{\mathrm{ab}} \\
\pm 0.047\end{array}$ & $\begin{array}{c}1.34^{\mathrm{b}} \\
\pm 0.081\end{array}$ & $\begin{array}{l}1.54^{\mathrm{ab}} \\
\pm 0.14 \\
\end{array}$ & $\begin{array}{l}1.59^{\mathrm{ab}} \\
\pm 0.12\end{array}$ \\
\hline $\begin{array}{l}\text { Liver function } \\
\text { AST, (IU/ml) }\end{array}$ & $\begin{array}{r}24.26 b^{c} \\
\pm 0.94\end{array}$ & $\begin{array}{l}28.03^{\mathrm{b}} \\
\pm 1.94 \\
\end{array}$ & $\begin{array}{l}34.06^{\mathrm{a}} \\
\pm 0.94 \\
\end{array}$ & $\begin{array}{l}17.25^{\mathrm{d}} \\
\pm 0.54\end{array}$ & $\begin{array}{l}21.56^{\mathrm{c}} \\
\pm 2.16 \\
\end{array}$ & $\begin{array}{l}26.96^{\mathrm{b}} \\
\pm 1.08 \\
\end{array}$ \\
\hline ALT, (IU/ml) & $\begin{array}{l}17.25^{\mathrm{c}} \\
\pm 0.54\end{array}$ & $28.03^{\mathrm{b}} \pm 1.94$ & $\begin{array}{l}42.25^{\mathrm{a}} \\
\pm 1.53\end{array}$ & $\begin{array}{l}25.88^{\mathrm{b}} \\
\pm 0.93\end{array}$ & $\begin{array}{l}29.11^{\mathrm{b}} \\
\pm 1.62\end{array}$ & $\begin{array}{c}26.47^{\mathrm{b}} \\
\pm 0.59\end{array}$ \\
\hline
\end{tabular}

a, b, and ${ }^{2}$ : Means within the same row with different superscripts are significantly different $(\mathrm{P}<0.05)$.

Rabbits fed 3\% rosemary had higher serum globulin, $(1.78, \mathrm{~g} / \mathrm{dl})$ as compared to the control, $1.5 \%$ rosemary, $1.5 \%, 3 \%$ marjoram and mixture $(1.49,1.76,1.66,1.42$ and 1.52 , respectively). The increase in the globulin fraction indicates the effective role of rosemary in increasing immunity due to its role in developing and protecting cells and inhibiting non-enzymatic oxidation (Houghton et al., 1995). These results in agreement with Ghazalah and Ali (2008) showed that rosemary leaves meal (at 0.5 and $1 \%$ of the diet) increased the globulin level in broilers as compared to the control group. However, Aboelazab (2015)observed no significant effect on serum globulin 
due to feeding rabbits diet supplemented with diets containing $0.5 \%$ and $1.0 \%$ rosemary leaves.

Rabbits fed mixture (1.5\%rosemary and $1.5 \%$ marjoram) diet had higher serum glucose $(118.20 \mathrm{~g} / \mathrm{dl})$ compared to control group and other treatments. However, feeding rabbits on $1.5 \%$ of rosemary or marjoram significantly $(\mathrm{P}<0.05)$ reduced serum glucose compared with the control group and other treatments. This result is in the same trend with Osman et al. (2010) indicated that feeding broilers with rosemary (Rosmarinus officinalis) at the level of $1 \mathrm{~g} / \mathrm{kg}$ diet significant decreased serum glucose. On contrary, ELnaggar et al., (2016). showed that broilers chicks fed 0.25, 0.50, 0.75 and $1 \%$ rosemary leaves meal had significantly $(\mathrm{P}<0.05)$ higher blood glucose compared with control group.

Rabbits fed diets supplemented with $1.5 \%$ and $3 \%$ marjoram had the highest $(\mathrm{P}<0.05)$ serum cholesterol $(93.80$ and $100.87 \mathrm{mg} / \mathrm{dl})$ respectively. However, Feeding diets supplemented with $1.5 \%$ and $3 \%$ rosemary had tendency to decrease serum concentration of cholesterol (74.22 and 73.37 $\mathrm{mg} / \mathrm{dl}$ ), respectively as compared to the other treatments. The reduced content of total cholesterol may reflect the hypocholesterolemic properties attributed to the defatted part of the leaves which are rich in fibrous (21.71\%) content and may block intestinal cholesterol absorption (Lansky et al., 1993). This finding is consistent with a study of total cholesterol performed by Ghazalah and Ali (2008), who fed chickens diets supplemented with $0.5,1.0$ and $2.0 \%$ dried Rosmarinus officinalis L. Their results showed that addition of rosemary leaves in the broiler diet lowered plasma content of total cholesterol levels. Also, Alagawany and Abd ElHack (2015) demonstrated that serum cholesterol decreased by supplementation of $3000 \mathrm{mg} / \mathrm{kg}$ rosemary powder to laying hen diets. In another study, Polat et al., (2011) observed that serum levels of cholesterol were reduced by supplementation of rosemary essential oils to broiler diets.

Growing rabbits fed diet supplemented with 1.5 and $3 \%$ marjoram had significantly higher serum total lipids (238.33 and $249.00 \mathrm{mg} / \mathrm{dl}$ ) compared with control andother treatments. However the rabbits fed control diet had the lower total lipids $(221.67 \mathrm{mg} / \mathrm{dl})$. This result is in agreement with Alagawany and Abd El-Hack (2015) who found that chicks fed diet supplemented with rosemary decreased serum total lipids.

\section{Kidney function}

Data in Table (6) indicated that there is no significant effect in serum urea-N due to feed medicinal plants. Serum creatinine significantly $(\mathrm{P} \leq 0.05)$ increased $(1.83 \mathrm{mg} / \mathrm{dl})$ in rabbits fed diet supplemented with 1.5 
rosemary as compared to the lowest creatinine $1.34 \mathrm{mg} / \mathrm{dl}$ as a result of feeding lower dietary marjoram $(1.5 \%)$. However rabbits fed $1.5 \%$ and $3 \%$ marjoram decreased blood serum creatinine $(1.34$ and $1.54 \mathrm{mg} / \mathrm{dl})$. This result is in agreement with Ali (2014) who showed that supplementing marjoram to broiler diet significantly reducing blood serum creatinine. However, Ahmed and Abdel-Ghany (2015).reported non-significant effect of marjoram on turkey birds fed diet supplemented with marjoram.

\section{Liver function}

Regarding the liver function, data indicated that supplementing growing rabbits diets with rosemary $(3 \%)$ caused a significant $(\mathrm{P} \leq 0.05)$ increase in AST and ALT (34.06 and $42.25 \mathrm{IU} / \mathrm{ml}$ ) when compared to those of the control of 21.26 and $17.25 \mathrm{~g} / \mathrm{dl}$, respectively. This result is in agreement with Chiofalo et al. (2012) who found that rosemary Rosmarinus officinalis extract supplementation in dairy ewes increased $(\mathrm{P} \leq 0.05)$ blood concentrations of AST and ALT. However, Osman et al. (2010) indicated that feeding broilers with rosemary (Rosmarinus officinalis) at the level of $1 \mathrm{~g} / \mathrm{kg}$ diet had no significant effect on AST and ALT.

Seleem et al. (2007) found that adding 3\% marjoram (Origanum majorana) to growing NZW rabbits diets increased significantly $(\mathrm{P} \leq 0.05)$ the concentrations of serum transaminase enzymes(AST and ALT), but this increase was still within normal range.

\section{Hematological parameters}

Hematological traits data for growing rabbits at 90 days of age fed basal diets supplemented with rosemary, marjoram and their mixture are summarized in Table (7). Addition of any of natural feed additives to rabbit diets did not significantly affect mean corpuscular volume (MCV), mean corpuscular hemoglobin $(\mathrm{MCH})$, and mean corpuscular hemoglobin concentration (MCHC), White blood cells (WBC) and platelets. These results are in the same trend with Al-Shuwaili (2014) who did not find any significant difference in $\mathrm{MCV}, \mathrm{MCH}, \mathrm{MCHC}$. WBCs of broiler chickens that fed on diets supplemented with $0.5 \%$ rosemary dry leaves.

Feeding growing rabbits on control, 1.5 rosemary and $1.5 \%$ marjoram had a significant tendency $(\mathrm{P} \leq 0.05)$ to increase serum hemoglobin $(12.36$, 11.82 and $12.32 \mathrm{~g} / \mathrm{dl}$ ), respectively as compared to the lowest hemoglobin $10.93,11.13$ and $10.94 \mathrm{~g} / \mathrm{dl}$ as a result of feeding upper dietary rosemary, marjoram $(3 \%)$ and their mixture. 
Table 7. Effect of dietary levels of natural feed additives on blood hematological parameters of growing NZW rabbits.

\begin{tabular}{|c|c|c|c|c|c|c|}
\hline \multirow[t]{3}{*}{ Items } & \multicolumn{6}{|c|}{ Treatments } \\
\hline & \multirow{2}{*}{ Control } & \multicolumn{2}{|c|}{ Rosemary } & \multicolumn{2}{|c|}{ Marjoram } & \multirow{2}{*}{ Mixture } \\
\hline & & $1.5 \%$ & $3 \%$ & $1.5 \%$ & $3 \%$ & \\
\hline $\begin{array}{l}\text { Hemoglobin , } \\
\text { (g/dl) }\end{array}$ & $\begin{array}{l}12.36^{\mathrm{a}} \\
\pm 0.21 \\
\end{array}$ & $\begin{array}{l}11.82^{\mathrm{a}} \\
\pm 0.12 \\
\end{array}$ & $\begin{array}{l}10.93^{\mathrm{b}} \\
\pm 0.15 \\
\end{array}$ & $\begin{array}{l}12.32^{\mathrm{a}} \\
\pm 0.28 \\
\end{array}$ & $\begin{array}{l}11.13^{\mathrm{b}} \\
\pm 0.07 \\
\end{array}$ & $\begin{array}{l}10.94^{\mathrm{b}} \\
\pm 0.14 \\
\end{array}$ \\
\hline $\begin{array}{l}\text { Red blood cells, } \\
\left(\mathrm{N} \times 10^{6} / \mathrm{mm}^{3}\right)\end{array}$ & $\begin{array}{l}4.77^{\mathrm{a}} \\
\pm 0.27\end{array}$ & $\begin{array}{l}4.31^{\mathrm{abc}} \\
\pm 0.04\end{array}$ & $\begin{array}{l}4.08^{\mathrm{c}} \\
\pm 0.05\end{array}$ & $\begin{array}{l}4.67^{\mathrm{ab}} \\
\pm 0.23\end{array}$ & $\begin{array}{l}4.19^{\mathrm{bc}} \\
\pm 0.052\end{array}$ & $\begin{array}{l}4.13^{\mathrm{c}} \\
\pm 0.07\end{array}$ \\
\hline Hematocrit (\%) & $\begin{array}{l}36.83^{\mathrm{a}} \\
\pm 0.65\end{array}$ & $\begin{array}{l}35.65^{\mathrm{a}} \\
\pm 0.41\end{array}$ & $\begin{array}{l}32.57^{b} \\
\pm 0.42\end{array}$ & $\begin{array}{l}37.05^{\mathrm{a}} \\
\pm 0.85\end{array}$ & $\begin{array}{l}33.28^{\mathrm{b}} \\
\pm 0.095\end{array}$ & $\begin{array}{l}32.79^{\mathrm{b}} \\
\pm 0.35\end{array}$ \\
\hline $\operatorname{MCV}(\mathrm{fl})$ & $\begin{array}{l}77.57 \\
\pm 3.19\end{array}$ & $\begin{array}{l}82.77 \\
\pm 0.58\end{array}$ & $\begin{array}{l}79.37 \\
\pm 0.32\end{array}$ & $\begin{array}{l}79.50 \\
\pm 2.24\end{array}$ & $\begin{array}{l}79.40 \\
\pm 0.75\end{array}$ & $\begin{array}{l}80.43 \\
\pm 0.72\end{array}$ \\
\hline MCH (pg) & $\begin{array}{c}25.97 \pm 1 \\
08\end{array}$ & $\begin{array}{l}27.40 \\
\pm 0.17\end{array}$ & $\begin{array}{l}26.53 \\
\pm 0.12 \\
\end{array}$ & $\begin{array}{l}26.40 \\
\pm 0.83\end{array}$ & $\begin{array}{l}26.53 \\
\pm 0.27\end{array}$ & $\begin{array}{l}26.80 \\
\pm 0.20\end{array}$ \\
\hline MCHC (\%) & $\begin{array}{l}33.47 \\
\pm 0.09 \\
\end{array}$ & $\begin{array}{l}33.13 \\
\pm 0.07 \\
\end{array}$ & $\begin{array}{l}33.27 \\
\pm 0.03 \\
\end{array}$ & $\begin{array}{l}33.20 \\
\pm 0.15 \\
\end{array}$ & $\begin{array}{l}33.40 \\
\pm 0.15 \\
\end{array}$ & $\begin{array}{l}33.30 \\
\pm 0.06 \\
\end{array}$ \\
\hline $\begin{array}{l}\text { White blood cells } \\
\left(\mathrm{N} \times 10^{3} / \mathrm{mm}^{3}\right)\end{array}$ & $\begin{array}{l}7.51 \\
\pm 0.28\end{array}$ & $\begin{array}{c}6.91 \\
\pm 0.33\end{array}$ & $\begin{array}{c}7.48 \\
\pm 0.29\end{array}$ & $\begin{array}{r}7.78 \\
\pm 0.188 \\
\end{array}$ & $\begin{array}{c}6.92 \\
\pm 0.35\end{array}$ & $\begin{array}{r}7.53 \\
\pm 0.39 \\
\end{array}$ \\
\hline Platelets ( mm) & $\begin{array}{c}319.33 \\
\pm 7.22\end{array}$ & $\begin{array}{r}309.67 \\
\pm 13.04\end{array}$ & $\begin{array}{l}308.67 \\
\pm 14.66\end{array}$ & $\begin{array}{c}337.33 \\
\pm 9.74\end{array}$ & $\begin{array}{l}308.67 \\
\pm 14.66\end{array}$ & $\begin{array}{l}314.00 \\
\pm 12.34\end{array}$ \\
\hline
\end{tabular}

$a, b$, and $:$ Means within the same row with different superscripts are significantly different $(\mathrm{P}<0.05)$.

Rabbits fed diets without any medicinal additives had significant $(\mathrm{P} \leq$ $0.05)$ higher red blood cells $\left(4.77 \mathrm{~N} \times 10^{6} / \mathrm{mm}^{3}\right)$ compared with other treatments. However, the rabbits fed $3 \%$ rosemary had the lowest red blood cells $\left(4.08 \mathrm{~N} \mathrm{x} 10^{6} / \mathrm{mm}^{3}\right)$ followed with mixed group $\left(4.13 \mathrm{~N} \mathrm{x} 10^{6} / \mathrm{mm}^{3}\right)$.

Plasma hematocrit significant increased $(\mathrm{P} \leq 0.05)$ in rabbits fed control, $1.5 \%$ rosemary and $1.5 \%$ marjoram $(36.83,35.65$ and $37.05 \%$, respectively) compared with the other groups. The lowest hematocrit level was in rabbits fed diet supplemented with 3\% rosemary, 3\% marjoram and their mixture (32.57, 33.28 and $32.79 \%)$.

In conclusion, inclusion of $1.5 \%$ of rosemary (Rosmarinus officinalis) or marjoram (Origanum majorana) plants in NZW rabbit rations as a natural source of antioxidants improved live body weight, body weight gain, carcass traits, digestibility of nutrients and economic efficiency under north Sinai conditions without any adverse effects in on performance. 
EFFECTS OF ROSEMARY \& MARJORAM SUPPLEMENTATION ONRABBITS 261

\section{REFERENCES}

Abd El-Galil, K. (2007). Effect of some feed additives on performance of laying Japanese quail.1- Effect of Marjoram leaves meal as a feed additive in laying Japanese quail diets. J. Agric. Sci., Mansoura Univ., 32(7): 5167-5179.

Abd El-Latif, S.A.A.; El-Yamany, A.T. and Edaly, E.A.F. (2004). Evaluation of using different levels and sources of medicinal herbs in growing Japanese quail diets. Egyptian Journal of Nutrition and Feeds, 7 (1), pp. 69-81.

Aboelazab, O.M. (2015) Effect of some natural antioxidants supplementation on productive performance of rabbits under heat stress conditions. Ph.D. Thesis, Faculty of Agriculture, Ain Shams University, Egypt.

Aboul-fotouh, G. E.; Allam, S. M.; Shehat, E. and Abdel-Azeem, S. N. (1999). Effect of some medicinal plants as feed additives on performance of growing sheep. Egypt J. Nutr. And Feeds, 2: 79-87.

Abousekken, M.S.M., Fahmy, A.A. and Ahmed, S.Z.S. (2007). Performance of growing rabbits fed different levels of Fennel and Marjoram byproducts and their mixture under desert environmental conditions. $9^{\text {th }}$ International Conf. Nut. and Feeds, 12-15 Nov., Luxor, Egypt.

Ahmed, E.G. and Abdel-Ghany, A.M. (2015). The effect of Origanum majorana supplementation on growth performance blood parameters and meat quality in BUT9 commercial turkeys. Journal of Animal, Poultry and Fish Production. Suez Canal University, (3): 17 -29.

Alagawany, M. and Abd El-Hack, M.E. (2015). The effect of rosemary herb as a dietary supplement on performance, egg quality, serum biochemical parameters, and oxidative status in laying hens. Journal of Animal and Feed Sciences, 24: 341-347.

Ali, A. H. H. (2014). Productive performance and immune response of broiler chicks as affected by dietary Marjoram leaves powder. Egypt. Poult. Sci., 34 (I): 57-70.

Al-Shuwaili, M.A. (2014). The effect of adding (Rosemarinusofficinalis) and (thymus vulgaris) to broilers diet on immune response and some physiological parameters of broilers. J. Kerbala Univ., 12(1): 92-97.

Allam, S. M.; Abou-Ammou, F. F.; Farghaly, M. S. and Othman, A. A. (2005). Effect of some natural antioxidations on lambs performance. 1-Carcass characteristics of lambs fed partial full fat soybean with natural additives. Egyptian J. Nutrition and Feeds, 8(1):275. 
Asar, M. A., Mona Osman, Yakout, H. M. and Safoat, A. (2010). Utilization of corn-cob meal and fiber bean straw in growing rabbit diets and their effects on performance, digestibility and economical efficiency. Egypt. Poult. Sci., Vol (30) (II): (415-442).

A.O.A.C. (2010).Official Methods of Aalysis.6thEdn., Association of Official Analytical Chemists, Washington, DC., USA.

Bauer, D. (1970). Numerical evaluation of red blood cells, white blood cells and platelets. In Gradwhol's Clinical Laboratory Methods and Diagnosis. 7th ED ,. Edited by Frankl, S,. S. Reitman and A.C. Sonnenwirth,C.V. Mpsbyco. London .

Chiofalo, V.; Liotta, L.; Fiumanò, R.; Benedetta, E. R. and Chiofalo, B. (2012).Influence of dietary supplementation of Rosmarinusofficinalis L. on performances of dairy ewes organically managed. Small Ruminant Research, 104, 122-128.

Coles, E.H. (1986). Veterinary Clinical Pathology (4thedn), WB Saunders, Philadelphia. pp: 56-58.

Cowan, M.M. (1999). Plant products as antimicrobial agents. Clinical Microbiology Reviews, 12, 4: 564- 582.

Deutsche VeterinaermedizinischeGesellschaft (1976). Arbeitswertefuer die tieraerztliche praxis, Beilagezu: tieraerztl. Prax. 4.4: 83-102.

Duncan, D.B. (1955). Multiple Range and Multiple F-test. Biometrics, 11: $1-42$.

EL-Ayek, M. Y. (1999). Influence of substituting concentrate feed mixture by Nigella sativa meal on: 1- Voluntary intake, digestibility, some rumen parameters and microbial protein yield with sheep. Egypt J. Nutr. and Feeds, 2: 279-296.

El-Kerdawy, D.M.A.; Ibrahim, A. and Ahmed, S.S. (1998). Reproductive performance of New Zealand White rabbits as affected by partial substitution of barley with date seeds. Egyptian J. Rab. Sci., 8 (1): 1-15.

ELnaggarAsmaa, Sh.; Abdel-LatifMervat, A.; El-Kelawy, M.I. and Abd EL-Hamid, H.S. (2016). Productive, physiological and immunological effect rosemary leaves meal (Rosemarinusofficinalis) supplementing to broiler diet. Egypt. Poult. Sci., (36): 859-873.

El-Wardany, I.; El-Badawi, A.Y.; Helal, F.I.S.; Ali, G.M. and Aboelazab, O.M. (2015). Growth performance and hematological changes of growing New Zealand White rabbits fed diets supplemented with some natural antioxidants under heat stress conditions. Egyptian J. Nutrition and Feeds, 18(2) Special Issue: 237-245.

Evans, F. J. and Pharm, B. (1975).Herbs, A Concise Guide. (Cited by Abd El-Latif et al., 2002). 
Ewuola, E. O.; Sokunbi, O. A.; Imam, T. K. and Amadi, C. U. (2011). Influence of dietary prebiotics and probiotics on blood profile of rabbits. Proc. 36th Ann. Conf. Nig. Soc. Anim. Produc.,13th - 16th March 2011 University of Abuja, Nigeria. Pp 171 - 173.

Ezz El-Arab, W. F. (2008). Productive, physiological, immunological and economical effects of supplementing natural feed additives to broiler diets. M. Sc. Thesis Faculty of Agriculture, Alexandria University, Egypt.

Ghazalah, A. A. and Ali, A. M. (2008). Rosemary leaves as a dietary supplement for growth in broiler chickens. Int. J. Poult. Sci., 7 (3): 234-239.

Guo, F. C. (2003). Mushroom and herb polysaccharides as alternative for antimicrobial growth promoters on poultry. Ph.D. Thesis, Wageningen Institute of Animal Sciences, Dep. Anim. Nutr., Wageningen Univ., Wageningen, Netherlands.

Hallnet, Ltd. (2014). http://www.herbwisdom.com/herbmarjoram. html.

Henry, R. J. and Cannon, D. C. (1974). Clinical chemistry - principles and Techniques. 2nd ed., Hoeber, New York

Houghton, J.; Zarka, R.; Heras, B.I. and Houtt, J.R.S. (1995). Fixed oil of Nigella satriva and derived thymoquinone inhibit eicosanoid generation in leukocytes and membrane lipid peroxidation. Plant Medica, 61: 33-36.

Husdan,H. and Rapoport, A. (1968).Estimation of creatinine by Jaffe reaction. Clin. Chem., 14,222-228.

Ibrahim, Sh. A. M. (2005). Effect of some medicinal plants as feed additives on growth and some metabolic changes in rabbits. Egyptian J. Nutr. and Feeds, 8: 207-219.

Lanksy, P.S.; Schilcher, H.; Phillipson, J.D. and Loew, D. (1993).Plants that lower cholesterol. First World Congress on Medicinal and Aromatic Plants (WOCMAP) for human welfare, Maastricht, Netherlands, Acta-Horticulture, 332: 131-136.

NRC (1977).National Research Council.Nutrient Requirements of Rabbits. Washington, DC. USA.

Omer, H.A.A.; EL-Nomeary, Y.A.A.; EL-Kady, R.I.; Badr, Azza M.M.; Ali, F.A.F.; Ahmed, Sawsan M.; EL-Allawy, H.M.H., and Ibrahim, Sh.A.M. (2013). Improving the utilization of rabbit diets containing vegetable oil by using fennel (Foeniculum vulgare) and oregano (Origanum vulgare L) as feed additives. Life Science Journal, 10(1): 2625-2636. 
Osman Mona, H. M.; Yakout, Motawe, H. F. and Ezz El-Arab, W. F. (2010).Productive, physiological, immunological and economical effects of supplementing natural feed additives to broiler diets. Egypt. Poult. Sci., 30 (1): 25-53.

Patton, C.J. and Crouch, S.R. (1977) Enzymatic calorimetric method to determine urea in serum. Anal. Chem., 49, 464-469.

Polat, U.; Yesilbag, D. and Eren, M.(2011).Serum biochemical profile of broiler chickens fed diets containing rosemary and rosemary volatile oil. Journal of Biol. Environ. Sci., 5(13): 23-30.

Reinhold, J.G. (1953). Manual determination of total serum proteins, albumin and globulin fractions by Biuret method In: Reiner, M. (Ed), Standard methods of clinical chemistry. Academic Press, New York.

Reitman, S. and Frankel, S. (1957). A colorimetric method for the determination of serum glutamic oxaloacetic and glutamic pyruvic transaminases. American Journal of Clinical Pathology, 28:56-63.

SAS Institute Inc., (2004). SAS procedures Guide for personal Computers, Statistical Analysis System Institute, Inc., Cary, N.C.

Seleem, T. S.T.; Ibrahim, H.; Ali, A. M.; Abd-Elmotaal, A. M. and Zeidan, A. E. B. (2007). Rabbit performance as affected by Origanummajoranain diets. $5^{\text {th }}$ Int. Conf. Rabbit Production in Hot Climates, 8-10 Oct., Hurghada, Egypt, 495-508.

Schalm, O. W. (1979). Veterinary Hematology. 4th Ed lea and febiger, Philadelphia. Press, New York.

Schiemann, R.; Nehring, K.; Hoffman, L.; Jentsch, W.; Chudy, A. (1972). Energetischefutterbewertung and energienormen. VEB Deutscher Landwirt schaftsveriag. Berlin. P. 344.

Schmit, J.M. (1964). Colorimetric determination of total lipids using sulfophosphovanilic mixture. Thesis, Lyon Biomerieurx - Comp. of France.

Steven, W. D.; Hohenboken, W. D.; Cheeke, P. R.; Patton, N. M. and Kennick, W. H. (1981).Carcass and meat characteristics of Flernish Giant and New Zealand White purebred and terminal cross rabbits. $J$. App. Rabbit Res., 4: 66.

Taha, A.T.; Al-baddy, M.A. and Saeid, J.M. (2011) Effect of oregano (Oregano vulgaris) supplementation on the performance and blood parameters of ross broiler chickens reared under heat stress conditions. Diyala Agricultural Sciences Journal, 2 (3): 59 - 49. 
EFFECTS OFROSEMARY \& MARJORAM SUPPLEMENTATION ONRABBITS 265

Triantaphyllou, K., G. Blekas and D. Boskou (2001). Ant oxidative properties of water extracts obtained from herbs of the species Lamiaceae. International-Journal-of-Food-Sciences-and Nutrition, 52 (4): 313-317.

Tipu, M. A.; Akhtar, M. S.; Anjum, M. I.; and Raja, M. I. (2006). Newdimension of medicinal plants as animal feed. Pakistan Vet. Journal, 2006, 26(3): 144-148.

Wintrobe (1967). Clinical Hematology. $6^{\text {th }}$ Ed Lea and Febiger , Philadelphia , 415-427.

\section{تأثير التغذية علي علائق الحصالبان والبردقوش علي النمو والهضم

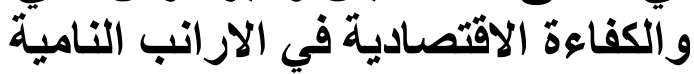

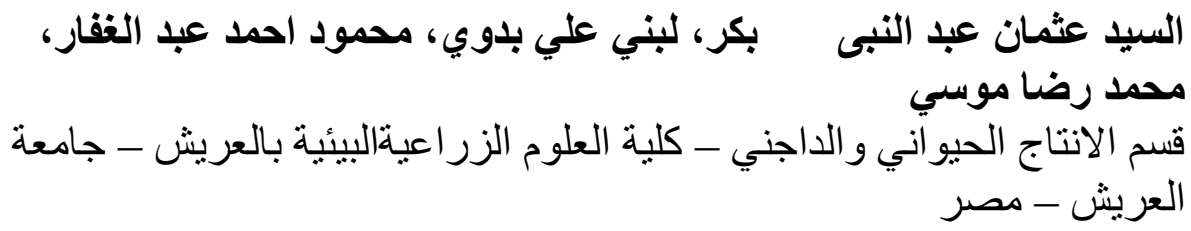

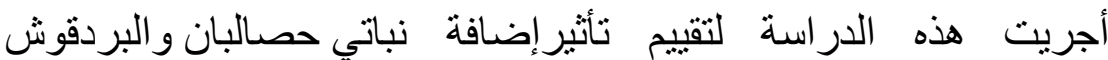

علمعاملات الهضم و الخصائص الانتاجية الار انب النيوزيلندى الأبيض تحت

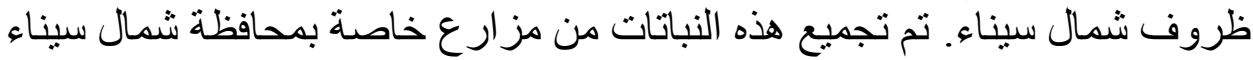

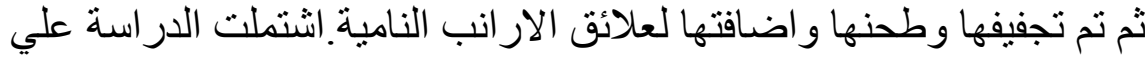

تجربيتين اساسيتين، اجريت التجربة الاولي علي 18 ذكر نيوز لاندي ابيض عمر 3

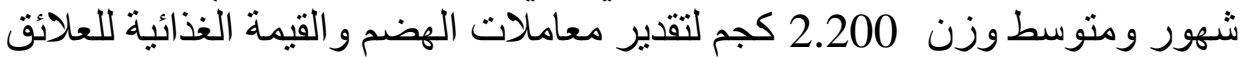
التجريبية ، اما التجربة الثانية اجريت علي عدد 72 ارنب نيوز لاندي ابيض نامي

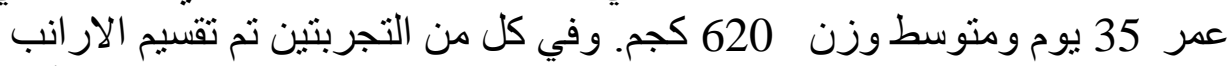

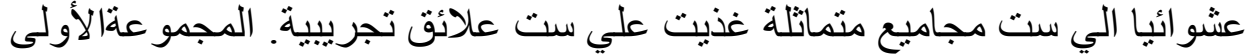

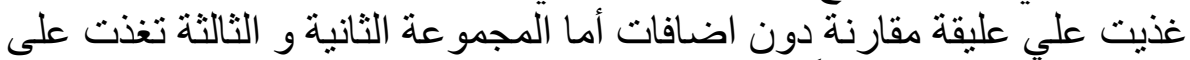
نفس العليقة و لكن مضافاً إليها 1.5\% و \% \% نبات الحصالبان أما المجموعة الر ابعة

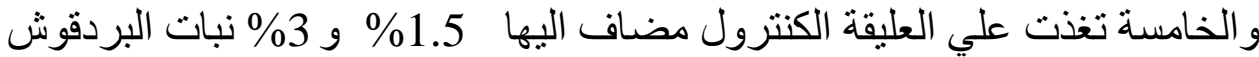
بينما غذيت المجموعة السادسة علي خليط من تباتي الحصالبان و البردقوش بنسب \% (1.5\% حصالبان + 1.5\% بردقوش).

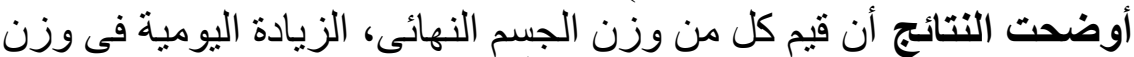

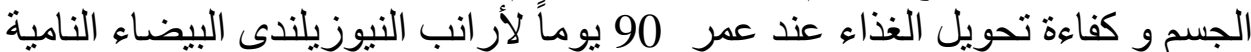


كانت أعلى معنوياً (عند مستوى 5\% 5) في المجمو عات المغذاة علي علائق مضاف البها خليط من ( 1.5\% نبات الحصالبان+ بمجمو عة الكنترول و المعاملات الأخرى.

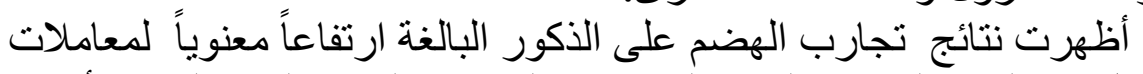

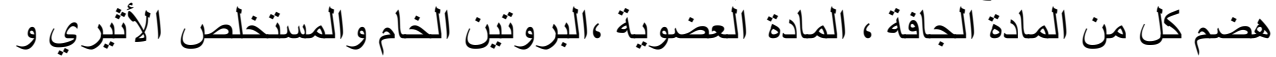

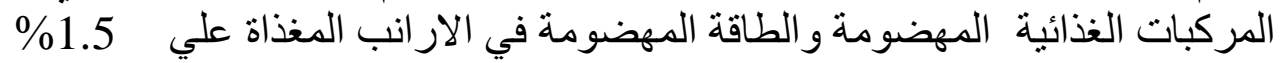
نبات الحصالبان مقارنة بباقي المعاملات ـ بينما اظهرت النتائج تفوق المجمو عات التاته

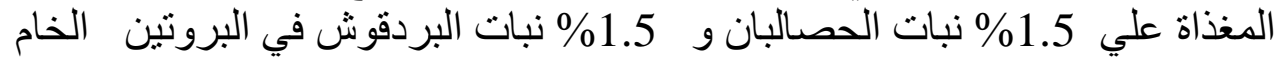
المهضوم بالمقارنة بياقي المعاملات.

اما بنسبة لصفات الذبيحة أظهرت أر انب المجمو عة المعاملة زيادة معنوية

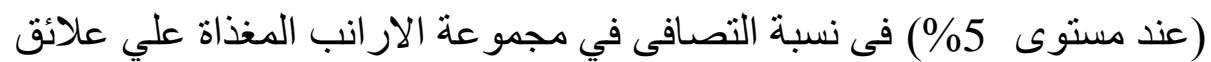

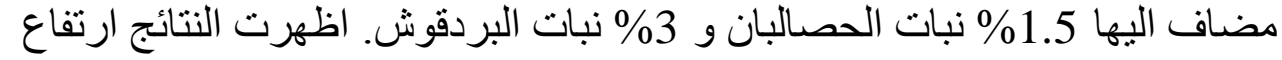

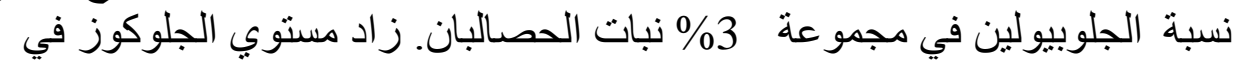

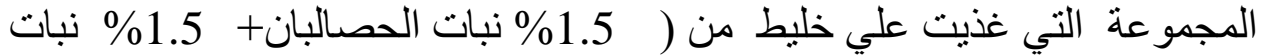

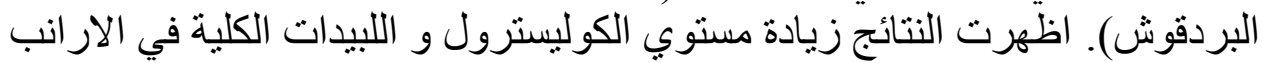

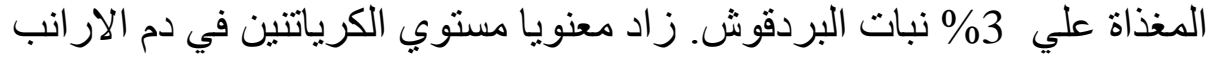

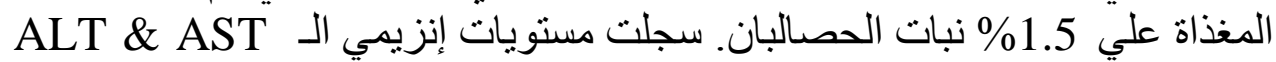

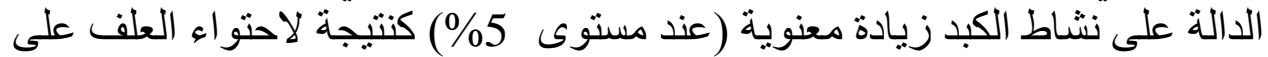

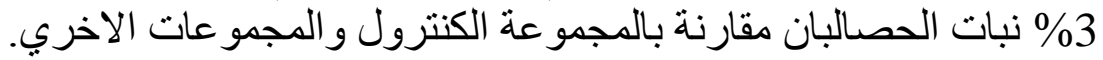

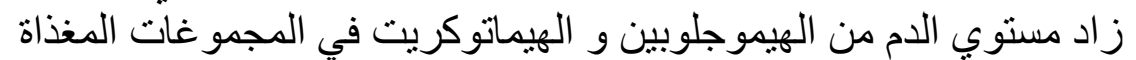

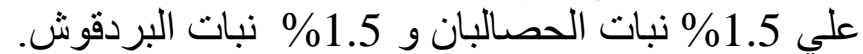

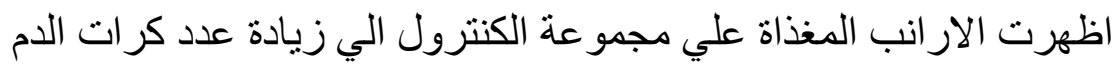

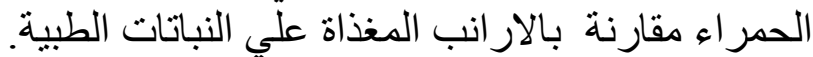

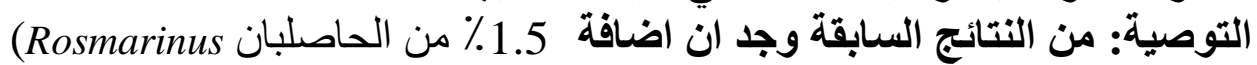

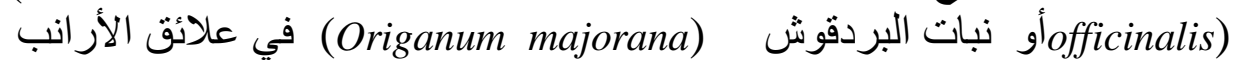

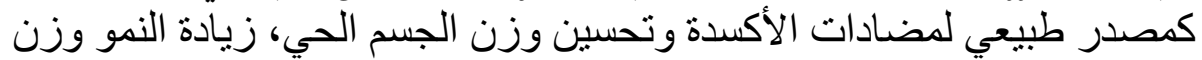

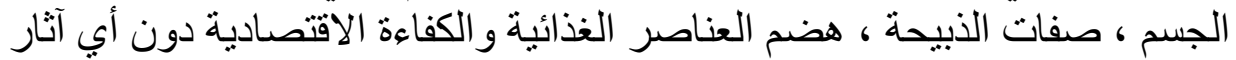
سلبية في الأداء الانتاجى للار انب. لانبه 